\title{
MODEL PEMBELAJARAN PROBLEM BASED LEARNING (PBL) SEBAGAI UPAYA MENINGKATKAN MOTIVASI DAN PRESTASI BELAJAR SEJARAH (PEMINATAN)
}

\author{
Rus Hartata \\ Guru Mata Pelajaran Sejarah SMAN 1 Polokarto Kab. Sukoharjo \\ rushartata@yahoo.co.id
}

\begin{abstract}
ABSTRAK
Tujuan penelitian adalah meningkatkan Motivasi belajar peserta didik dan prestasi belajar Sejarah (Peminatan) menggunakan Model Pembelajaran Problem Based learning (PBL) kelas XI IPS1 SMA Negeri 1 Polokarto semester Gasal tahun pelajaran 2019/2020. Penelitian dilaksanakan selama 4 bulan dimulai Agustus 2019 sampai November 2019, di kelas XI IPS1 SMA Negeri 1 Polokarto. Subyek penelitian: peserta didik kelas XI IPS1. Jumlah peserta didik 32. Prosedur Penelitian Tindakan Kelas dengan 2 siklus. Teknik pengumpulan data adalah teknik tes dan non tes. Alat pengumpul data berupa butir-butir soal tes tertulis dan lembar Observasi aktivitas belajar peserta didik yang dilakukan kolaborator. Hasil penelitian : Kondisi awal ke siklus 2 terjadi peningkatan motivasi belajar peserta didik dari ke-empat aspek yang dinilai yaitu : Aspek kehadiran tetap 100\%, aspek interaksi dengan guru meningkat dari $15,63 \%$ menjadi $93,75 \%$, aspek antusias dalam kelompok meningkat dari $0 \%$ menjadi $66,27 \%$, sedangkan aspek tanggung jawab dalam pembelajaran meningkat dari 15,63\% menjadi 93,75\%. Pada nilai prestasi dari kondisi awal ke siklus 2 meningkat dari nilai rerata 58,91 menjadi 80,16. Nilai tertinggi naik dari 75 menjadi 95, nilai terendah naik dari 45 menjadi 65 dan ketuntasan belajar meningkat dari 31,25\% menjadi 90,63\%.
\end{abstract}

\section{Kata kunci : Problem Based Learning (PBL), Motivasi Belajar, Prestasi Belajar.}

\section{PENDAHULUAN}

Pembelajaran di SMA Negeri 1 Polokarto khususnya di kelas XI IPS 1 banyak siswa kesulitan mempelajari Sejarah (Peminatan), hal ini terlihat dari hasil belajar yang rendah. Kesulitan belajar Sejarah (Peminatan) kemungkinan disebabkan beberapa faktor antara lain: cakupan materi Sejarah (Peminatan) terlalu banyak, bagi sebagian siswa merupakan materi yang dianggap sulit dan menjemukan, metode pembelajaran yang diterapkan oleh guru monoton sehingga suasana belajar terkesan kaku dan didominasi oleh sang guru, proses pembelajaran di kelas kurang meningkatkan kreativitas siswa, dalam pembelajaran kurangnya penggunaan media dan alat peraga serta kurangnya buku sumber yang tersedia di perpustakaan sekolah. Selain itu, banyak siswa yang 
malas belajar dan berlatih memecahkan atau menyelesaikan soal-soal Sejarah (Peminatan) jika tidak mendapat tugas dari guru. Banyak siswa yang tidak memiliki kesiapan ketika akan mengikuti pembelajaran Sejarah (Peminatan). Siswa tidak mengerti materi yang akan mereka pelajari dan gambaran materi itu. Siswa juga tidak mau membaca terlebih dahulu materi yang akan diajarkan, jika tidak mendapat tugas dari gurunya. Bahkan sebagian siswa beranggapan bahwa pelajaran Sejarah (Peminatan) merupakan pelajaran tambahan karena tidak disertakan dalam Ujian Akhir Nasional.

Dengan menggunakan model yang inovatif diharapkan dalam pembelajaran Sejarah (Peminatan) memberikan dampak positif terhadap peserta didik, yaitu semakin meningkatnya motivasi dan prestasi belajar peserta didik terhadap mata pelajaran Sejarah (Peminatan). Dengan Metode Problem Based Learning (PBL) diharapkan tujuan pembelajaran Sejarah (Peminatan) dapat dicapai dengan hasil yang maksimal, yang tentunya seorang guru bukan hanya sekedar memberi penjelasan secara lisan saja tetapi dapat menggunakan berbagai macam metode yang relevan dengan masalah yang sedang dibahas. Metode Problem Based Learning (PBL) diharapkan mampu memberikan dorongan pada proses pembelajaran Sejarah (Peminatan) menjadi menarik serta mampu meningkatkan prestasi peserta didik dalam setiap evaluasi pembelajaran yang diberikan.

Metode Problem Based Learning (PBL) didasarkan pada premis bahwa situasi masalah yang mengundang pertanyaan dan belum terdefinisikan dengan jelas, akan membangkitkan rasa ingin tahu peserta didik serta diharapkan melibatkan mereka dalam inkuiri. Situasi masalah yang dipilih hendaklah otentik, terdefinisikan secara longgar, bermakna dan selaras dengan intelektual peserta didik serta menguntungkan bagi kelompok. Kegiatan tugas struktur mempunyai kaitan yang erat dalam pelaksanaan model pembelajaran berbasis masalah dikarenakan tugas terstruktur dapat dilaksanakan secara perorangan maupun kelompok. Kerja kelompok mempunyai arti yang sangat penting untuk mengembangkan sikap bergotong royong, tenggang rasa, persaingan sehat, kerja sama dan kemampuan memimpin.

Berdasarkan latar belakang di atas, maka dalam penelitian ini permasalahan yang dikemukakan adalah sebagai berikut:

1) Apakah model pembelajaran Problem Based Learning (PBL) dapat meningkatkan motivasi belajar bagi peserta didik kelas XI IPS 1 untuk mata pelajaran Sejarah 
Model Pembelajaran Problem Based Learning (PBL)

Sebagai Upaya Meningkatkan Motivasi Dan Prestasi Belajar Sejarah (Peminatan)

(Rus Hartata)

(Peminatan) pada semester gasal SMA Negeri 1 Polokarto tahun pelajaran $2019 / 2020 ?$

2) Apakah model pembelajaran Problem Based Learning (PBL) dapat meningkatkan prestasi belajar bagi peserta didik kelas XI IPS 1 untuk mata pelajaran Sejarah (Peminatan) pada semester gasal SMA Negeri 1 Polokarto tahun pelajaran $2019 / 2020 ?$

Tujuan yang ingin dicapai dalam penelitian ini adalah : Untuk mengetahui ada tidaknya peningkatan motivasi dan prestasi belajar untuk mata pelajaran Sejarah (Peminatan) yang menggunakan model pembelajaran Problem Based Learning (PBL) dengan Role Play bagi kelas XI IPS 1 pada semester gasal SMA Negeri 1 Polokarto tahun pelajaran 2019/2020. Sedangkan manfaat yang dapat dipetik yaitu : Memberikan masukan dan wawasan bagi para pendidik yang memilih strategi pembelajaran khususnya model pembelajaran Problem Based Learning (PBL), serta memudahkan peserta didik untuk memahami mata pelajaran Sejarah (Peminatan), sehingga motivasi belajar dan prestasi belajar meningkat.

\section{LANDASAN TEORI DAN HIPOTESIS TINDAKAN}

\section{Pengertian Problem Based Learning (PBL)}

Problem Based Learning (PBL) adalah suatu pendekatan pembelajaran yang menggunakan masalah dunia nyata sebagai suatu kontek bagi peserta didik untuk belajar tentang cara berfikir kritis dan ketrampilan pemecahan masalah, serta untuk memperoleh pengetahuan dan konsep yang essensial dari materi pelajaran (Enny Puspita: 2010).

Pengertian Problem Based Learning (PBL) menurut Prof. Howard Barrows dan Kelson, adalah kurikulum dan proses pembelajaran. Dalam kurikulumnya dirancang masalah-masalah yang menuntut peserta didik mendapatkan pengetahuan yang penting, membuat mereka mahir dalam memecahkan masalah, dan memiliki strategi belajar sendiri serta memiliki kecakapan berpartisipasi dalam tim (Taufik Amir M.: 2010). Adapun menurut Sudarno dan Saiful Bachri pengertian Problem Based Learning (PBL) adalah model pembelajaran yang mendukung pemikiran tingkat tinggi dalam situasi yang beroreintasi masalah. 
Menurut Erna Tutik Yustiani (2011: 8) Problem Based Learning (PBL) adalah salah satu model pembelajaran yang berorientasi pada penyelesaian masalah (problem solving) dan dikembangkan dengan memanfaatkan teori-teori dari John Dewey. Menurut Arends Problem dengan Problem Based Learning (PBL) yaitu merupakan salah satu model pembelajaran yang digunakan untuk meningkatkan derajat berfikir ketingkat lebih tinggi dan berorientasi pada masalah.

Dari beberapa teori tersebut diatas dapat ditarik kesimpulan bahwa Problem Based Learning (PBL) mempunyai pengertian membantu peserta didik untuk mengembangkan ketrampilan berfikir dan ketrampilan mengatasi masalah, mempelajari peran-peran orang dewasa dan menjadikan pelajar yang mandiri.

\section{Tujuan Problem Based Learning}

Problem Based Learning $(P B L)$ adalah pedagogi yang berpusat pada peserta didik dimana peserta didik belajar tentang subjek dalam konteks masalah yang kompleks, multifaset, dan realistis (tidak harus bingung dengan pembelajaran berbasis proyek). Tujuan dari Problem Based Learning (PBL) adalah untuk membantu peserta didik mengembangkan pengetahuan yang fleksibel, keterampilan pemecahan masalah yang efektif, belajar mandiri, keterampilan kolaborasi yang efektif dan motivasi intrinsik.

\section{Langkah-Langkah Metode Problem Based Learning (PBL)}

Dalam Problem Based Learning (PBL) kelas dibagi menjadi beberapa peran, antara lain adalah guru, fasilitator, ketua dan sekretaris, dimana masing - masing mempunyai peran sebagai berikut:

1) Tugas fasilitator

a) Membimbing peserta didik dalam mendiskusikan/trigger

b) Meluruskan jalannya diskusi dan memfasilitasi interaksi dalam grup

c) Memberikan ide-ide utama agar para peserta didik tidak jauh dari pokok masalah

2) Tugas dari Ketua dalam Tutorial

a) Memimpin jalannya diskusi

b) Mampu mengatur urusan dalam setiap diskusi

c) Membagi tugas-tugas kepada anggota secara adil dan merata sehingga tidak didominasi oleh seseorang. 
Model Pembelajaran Problem Based Learning (PBL)

Sebagai Upaya Meningkatkan Motivasi Dan Prestasi Belajar Sejarah (Peminatan)

(Rus Hartata)

3) Tugas Sekretaris

Menulis hasil diskusi pada whiteboard dan menyimpulkan hasil diskusi. Metode Problem Based Learning (PBL) lebih meningkatkan kemampuan peserta didik dalam hal berfikir kritis dan mampu memecahkan masalah (problem solving learning) sedang belajar yang biasanya dilakukan secara konvesional dilakukan secara diskusi dengan menggunakan kelompok kecil yang merupakan poin utama dalam menetapkan Problem Based Learning (PBL).

\section{Ciri-Ciri Metode Problem Based Learning (PBL)}

Ciri khas Pembelajaran Berdasarkan Masalah yaitu :

1) Mengajukan pertanyaan atau masalah

2) Berfokus pada interdisiplin

3) Penyelidikan otentik

4) Menghasilkan karya nyata dan memamerkan

5) Kolaborasi

Hasil Belajar Utama Peserta Didik Dalam Metode Problem Based Learning (PBL)

\section{Meliputi:}

1) Keterampilan inkuiri dan pemecahan masalah

2) Mendapatkan perilaku-perilaku peran orang dewasa

3) Menjadi peserta didik mandiri atau otonom.

\section{Motivasi}

\section{Pengertian Motivasi}

Menurut David Mc. Clelland, Abraham Maslow dan Brown yang dikutip oleh Wahjosumidjo (1985: 174) mengemukakan bahwa pengertian motivasi sebagai berikut: "motivasi merupakan suatu proses psikologis yang mencerminkan interaksi dan sikap, kebutuhan, persepsi dan keputusan yang terjadi pada diri seseorang. Motivasi merupakan sebagai proses psikologis yang mencerminkan interaksi antara sikap, kebutuhan, persepsi dan keputusan yang terjadi pada diri seseorang".

Motivasi berasal dari kata latin moveer yang berarti menggerakkan. Kata motivasi lalu diartikan sebagai usaha menggerakkan (Printich \& Schunk, 1996). Secara istilah terdapat berbagai macam definisi motivasi yang disampaikan oleh para ahli, antara lain: definisi menurut Atkinson (1997) yang menyatakan motivasi adalah sebuah istilah yang mengarah kepada adanya kecenderungan bertindak untuk menghasilkan 
satu atau lebih pengaruh. Freud (1996) menyatakan bahwa motivasi adalah energi phisik yang memberi kekuatan kepada manusia untuk melakukan tindakan tertentu (dalam Printich \& Schunk, 1996). Chauhan (1979) mengutip pendapat A.W Bernard yang mendefinisikan motivasi sebagai sebuah fenomena yang melibatkan stimulation (perangsang tindakan ke arah tujuan-tujuan tertentu dimana sebelumnya kecil atau bahkan tidak ada (dalam Fudyartanto, 2002). Beberapa ahli yang lain sepeti Halpin, Payne, \& Ellert (1975), Freehill \& Mc Donald (1971), Zilli (1971) menekankan bagwa motivasi merupakan karekteristik personal yang menjadi energi, antusiasisme, semangat, kekuatan, keteguhan dan kebutuhan untuk berperilaku dan mencapai prestasi (dalam Dai, Moon, dan Fedhusen, 1998).

Walaupun berbagai macam istilah yang digunakan oleh para ahli dalam menyatakan hakekat motivasi tersebut, namun secara umum motivasi didefinisikan sebagai kondisi internal yang memunculkan, mengarahkan, dan menjaga sebuah perilaku. Dalam definisi demikian, maka pada dasarnya motivasi merupakan proses yang terjadi didalam diri individu yang mengarahkan aktivitas individu mencapai tujuan yang perlu didorong dan dijaga (Printich \& Schunk, 1996: 20). Sebagai sebuah proses, motivasi bukanlah sebuah produk, sehingga tidak mudah diamati secara langsung, tetapi dapat diketahui indikatornya dari perilaku yang tampak, seperti pemilihan tugas-tugas, usaha, keteguhan dan ucapan-ucapan secara verbal. "Saya yakin dapat menyelesaikan tugas-tugas ini" misalnya. Dalam motivasi mengandung tujuan-tujuan (goals) yang memberikan energi penggerak untuk mengarahkan tindakan seseorang.

Menurut Sardiman A.M (2007: 35), kata “motif”, diartikan sebagai daya upaya yang mendorong seseorang untuk melakukan sesuatu. Motif dapat dikatakan sebagai daya penggerak dari dalam dan subyek untuk melakukan aktifitas-aktifitas tertentu demi mencapai suatu tujuan. Bahkan motif dapat diartikan sebagai suatu kondisi intern (kesiapsiagaan). Berawal dari kata "motif" itu maka motivasi dapat diartikan sebagai daya penggerak yang telah menjadi aktif, Motif menjadi aktif pada saat tertentu, terutama apabila kebutuhan untuk mencapai tujuan yang sangat dirasakan (mendesak).

Dalam kegiatan belajar mengajar, apabila ada seseorang peserta didik, misalnya tidak berbuat sesuatu yang seharusnya dikerjakan, maka perlu diselidiki sebabsebabnya. Sebab-sebab itu biasanya bermacam-macam, mungkin ia tidak senang, mungkin sakit, lapar, ada problem pribadi, dan lain-lain. Hal ini berarti dalam diri anak 
Model Pembelajaran Problem Based Learning (PBL)

Sebagai Upaya Meningkatkan Motivasi Dan Prestasi Belajar Sejarah (Peminatan)

(Rus Hartata)

tidak terjadi perubahan energi, tidak terangsang afeksinya untuk melakukan sesuatu, karena tidak memiliki tujuan atau kebutuhan belajar. Keadaan semacam ini perlu dilakukan daya upaya yang dapat menemukan sebab-musababnya, kemudian mendorong seseorang peserta didik itu mau melakukan pekerjaan yang seharusnya dilakukan, yakni belajar. Dengan kata lain, peserta didik perlu diberikan rangsangan agar tumbuh motivasi pada dirinya. Atau singkatnya perlu diberikan motivasi.

\section{Hubungan Motivasi dengan Belajar}

Salah satu tugas guru dalam proses belajar mengajar adalah menciptakan lingkungan belajar yang dapat meningkatkan motivasi belajar peserta didik. Motivasi belajar peserta didik adalah kecenderungan peserta didik untuk menemukan aktivitas belajar yang bermakna dan berharga sehingga mereka merasakan keuntungan dari aktivitas belajar tersebut. Motivasi belajar peserta didik dibangun dari karakteristik peserta didik serta situasi dan kondisi tertentu.

Motivasi dapat mempengaruhi peserta didik saat mereka akan mempelajari materi yang baru atau pada saat mereka melakukan unjuk kerja dari ketrampilanketrampilan, strategi-strategi dan perilaku-perilaku yang sebelumnya telah dipelajari, dimana semua itu mempunyai implikasi yang penting bagi sekolah. Selain itu motivasi juga akan dapat mempengaruhi apa, kapan, dan bagaimana peserta didik belajar. Peserta didik yang termotivasi belajar ia akan menunjukkan antusias terhadap aktivitas-aktivitas belajar, serta memberikan perhatian penuh terhadap apa yang diinstruksikan oleh guru, selalu melakukan evaluasi diri terhadap pemahaman materi-materi yang dipelajarinya, serta memiliki komitmen yang tinggi untuk dapat memcapai tujuan belajar.

Namun tidak semua peserta didik memiliki motivasi yang tinggi dalam belajar. Maka dari itu, menurut Blumenfeld, (1992: 78) ada tiga tugas penting untuk guru berkaitan dengan memotivasi peserta didik belajar, yaitu: (1). mengajak peserta didik untuk secara produktif berpartisipasi dalam proses belajar di kelas, atau makna lain guru menciptakan kondisi motivasi belajar, (2). merancang tujuan jangka panjang untuk mengembangkan kepribadian peserta didik yang akan termotivasi untuk belajar sehingga mereka akan mampu untuk mendidik diri mereka sendiri sepanjang hidupnya, (3). mengajak peserta didik untuk dapat memiliki kemampuan berfikir secara mendalam terhadap apa yang mereka pelajari. 
Motivasi mempengaruhi strategi belajar dan proses kognitif yang digunakan peserta didik, sehingga mereka akan memberikan perhatian terhadap sesuatu, mempelajari dan mempraktekannya, dan mencoba belajar secara penuh makna, juga meningkatkan kemauan untuk mencari bantuan pada saat peserta didik menghadapi kesulitan. (Esa Nur Wahyuni, 1996: 38).

\section{Prestasi Belajar}

\section{Pengertian Prestasi Belajar}

Saifuddin Azwar (2009: 9) mengemukakan bahwa prestasi belajar merupakan bentuk penampilan maksimal seseorang dalam menguasai bahan atau materi yang telah diajarkan. Maknanya adalah sebuah kemampuan yang dapat diraih dan dimiliki peserta didik setelah mengikuti proses pembelajaran di dalam kelas. Kemampuan ini ditunjukkan dengan penguasaan terhadap suatu materi pembelajaran yang dibuktikan melalui suatu keberhasilan dalam menyelesaikan pelatihan.

Di bawah ini akan dikemukakan beberapa pengertian prestasi dan belajar menurut para ahli. Prestasi adalah hasil dari suatu kegiatan yang telah dikerjakan, diciptakan baik secara individu maupun secara kelompok (Djamarah, 1994: 19). Sedangkan menurut Mas'ud Hasan Abdul Dahar dalam Djamarah (1994: 21) bahwa prestasi adalah apa yang telah dapat diciptakan, hasil pekerjaan, hasil yang menyenangkan hati yang diperoleh dengan jalan keuletan kerja. Dari pengertian yang dikemukakan tersebut di atas, jelas terlihat perbedaan pada kata-kata tertentu sebagai penekanan, namun intinya sama yaitu hasil yang dicapai dari suatu kegiatan. Untuk itu, dapat dipahami bahwa prestasi adalah hasil dari suatu kegiatan yang telah dikerjakan, diciptakan, yang menyenangkan hati, yang diperoleh dengan jalan keuletan kerja, baik secara individual maupun secara kelompok dalam bidang kegiatan tertentu.

Menurut Slameto (1995: 2) bahwa belajar adalah suatu proses usaha yang dilakukan seseorang untuk memperoleh suatu perubahan tingkah laku yang baru secara keseluruhan, sebagai hasil pengalamannya sendiri dalam interaksi dengan lingkungannya. Secara sederhana dari pengertian belajar sebagaimana yang dikemukakan oleh pendapat di atas, dapat diambil suatu pemahaman tentang hakekat dari aktivitas belajar adalah suatu perubahan yang terjadi dalam diri individu. 
Model Pembelajaran Problem Based Learning (PBL)

Sebagai Upaya Meningkatkan Motivasi Dan Prestasi Belajar Sejarah (Peminatan)

(Rus Hartata)

Sedangkan menurut Nurkencana (1986: 62) mengemukakan bahwa prestasi belajar adalah hasil yang telah dicapai atau diperoleh anak berupa nilai mata pelajaran. Ditambahkan bahwa prestasi belajar merupakan hasil yang mengakibatkan perubahan dalam diri individu sebagai hasil dari aktivitas dalam belajar. Setelah menelusuri uraian di atas, maka dapat dipahami bahwa prestasi belajar adalah hasil atau taraf kemampuan yang telah dicapai peserta didik setelah mengikuti proses belajar mengajar dalam waktu tertentu baik berupa perubahan tingkah laku, keterampilan dan pengetahuan dan kemudian akan diukur dan dinilai yang kemudian diwujudkan dalam angka atau pernyataan.

Dari uraian di atas dapat ditarik kesimpulan bahwa prestasi belajar adalah suatu usaha maksimal yang dilakukan peserta didik setelah mengikuti proses pembelajaran di kelas yang diakhiri dengan tes, berupa kemampuan menguasai dan memahami materi pembelajaran peserta didik, diwujudkan dalam bentuk angka atau huruf atau kalimat yang menginformasikan sejauh mana penguasaan dan pemahaman materi pembelajaran. Prestasi belajar yang dicapai seseorang akan tergantung dari tingkat potensinya (kemauannya) baik yang berupa kecerdasan maupun bakat. Peserta didik yang berpotensi tinggi cenderung untuk memperoleh prestasi belajar yang tinggi pula, sebaliknya yang berpotensi rendah akan cenderung mendapat prestasi yang rendah pula.

\section{Kerangka Berfikir}

Belajar merupakan aktivitas yang ditempuh peserta didik dengan tujuan untuk membentuk sikap atau budi pekerti yang baik dalam kehidupan sehari-hari di sekolah, di rumah, dan di lingkungan masyarakat. Tujuan pembelajaran diduga dapat tercapai apabila guru dalam menyampaikan materi pembelajaran menggunakan pendekatan Problem Based Learning (PBL).

Pendekatan Problem Based Learning (PBL) merupakan pembelajaran yang mempertimbangkan keragaman peserta didik dan multi intelegensi peserta didik yang ada di kelas itu. Prestasi belajar atau hasil belajar merupakan puncak dari suatu proses pembelajaran. Pada mata pelajaran Sejarah (Peminatan) masih banyak ditemukan masalah-masalah antara lain: masih rendahnya prestasi belajar peserta didik, masih rendahnya tingkat partisipasi peserta didik, masih rendahnya tingkat pemahaman peserta didik terhadap konsep-konsep dasar Sejarah (Peminatan). 
Untuk itu diperlukan perhatian khusus yang berkaitan dengan pengembangan strategi pendekatan pembelajaran Sejarah (Peminatan) di sekolah. Salah satu pendekatan yang memberikan peluang besar untuk meningkatkan hasil belajar adalah pendekatan Problem Based Learning (PBL).

Peserta didik akan dibiasakan berinteraksi dengan peserta didik lain melalui belajar kelompok dan observasi langsung di lapangan. Peserta didik belajar bersamasama dalam kelompoknya yang terdiri dari berbagai macam tipe, artinya kelompok tersebut bersifat heterogen dan di dalamnya terdiri dari peserta didik yang tergolong pandai, sedang dan lemah. Jika ada anggota kelompok yang tidak jelas maka anggota kelompok yang merasa mampu akan menjelaskan pada peserta didik tersebut. Dengan demikian pembelajaran akan menyenangkan dan selanjutnya akan menimbulkan semangat belajar peserta didik dan diharapkan hasil belajar peserta didik akan meningkat.

\section{METODE PENELITIAN}

\section{Seting penelitian}

Waktu penelitian : Penelitian dilakukan selama empat bulan dengan mengambil data kondisi awal pada semester gasal dan pelaksanaan tindakan dilakukan pada semester gasal pada tahun pelajaran 2019/2020. Pelaksanaan penelitian tindakan dilakukan secara bertahap. Tempat penelitian adalah di SMA Negeri 1 Polokarto. Penelitian mengambil kelas XI IPS 1 dimana peneliti mengajar pada kelas tersebut.

\section{Subyek penelitian}

1) Peserta didik kelas XI IPS 1 SMA Negeri 1 Polokarto tahun pelajaran 2019/2020 yang berjumlah 32 peserta didik.

\section{Sumber Data.}

1) Data Kondisi awal yang berupa nilai harian dan data motivasi belajar peserta didik.

2) Data Siklus 1 yang berupa nilai prestasi pada akhir siklus dan data motivasi belajar peserta didik pada siklus 1.

3) Data Siklus 2 yang berupa nilai prestasi pada akhir siklus 2 dan data motivasi belajar peserta didik pada siklus 2 .

\section{Teknik dan Alat Pengumpulan Data.}

Metode pengumpulan data yang digunakan dalam penelitian ini adalah metode tes dan metode non tes. Metode tes digunakan untuk mengetahui nilai prestasi belajar dan 
Model Pembelajaran Problem Based Learning (PBL)

Sebagai Upaya Meningkatkan Motivasi Dan Prestasi Belajar Sejarah (Peminatan)

(Rus Hartata)

metode non tes digunakan untuk mengetahui data motivasi belajar peserta didik. Pada metode tes yang digunakan untuk mengukur prestasi belajar menggunakan butir soal dan pada metode non tes yang digunakan untuk penilaian motivasi belajar peserta didik menggunakan lembar observasi.

\section{Validasi Data}

Tes prestasi belajar menggunakan validitas isi yaitu yang berupa kisi-kisi soal dalam hal ini adalah mata pelajaran Sejarah (Peminatan). Untuk motivasi belajar peserta didik menggunakan Triangulasi data yaitu dari kolaborasi teman sejawat dalam hal ini adalah sesama guru Sejarah.

\section{Analisis Data}

Analisa data pada tes prestasi belajar menggunakan analisis deskriptif komparatif yaitu membandingkan nilai tes kondisi awal dengan nilai tes pada siklus 1 dan terakhir nilai tes pada siklus 2. Analisa data pada motivasi belajar peserta didik menggunakan analisis deskriptif kualitatif berdasarkan pada hasil observasi dan refleksi pada siklus 1 dan siklus 2 .

\section{Indikator Kerja}

Indikator kerja dapat dilihat secara umum dengan membandingkan tingkat keberhasilan dari satu siklus ke siklus berikutnya. Keberhasilan tindakan pada siklus 1 diketahui dengan cara membandingkan dengan kondisi awal peserta didik da keberhasilan tindakan pada siklus 2 diketahui dengan cara membandingkan dengaı siklus 1. Sedangkan indikator kerja tindakan dapat dilihat dari kriteria yang telah ditentukan peneliti, dengan kriteria apabila peserta didik kelas XI IPS 1 SMA Negeri Polokarto menunjukkkan hal-hal sebagai berikut:

1) Peningkatan Motivasi belajar peserta didik dari kondisi awal ke siklus 1 dan dari siklus 1 ke siklus 2 .

2) Peningkatan prestasi belajar dari kondisi awal ke siklus 1 dan dari siklus 1 ke siklus 2.

\section{Prosedur Penelitian}

Penelitian ini menggunakan rancangan penelitian tindakan kelas. Penelitian ini terdiri dari dua siklus. Masing-masing siklus melalui tahap perencanaan tindakan, pelaksanaan tindakan, observasi dan refleksi. Untuk menerapkan perangkat pembelajaran model Problem Based Learning ( $P B L$ ) digunakan rancangan penelitian 
tindakan dan memecahkan masalah-masalah praktis, serta memperbaiki strategi pembelajaran. Pada penelitian ini tindakan yang dimaksud adalah penerapan pembelajaran model Problem Based Learning ( $P B L$ ) untuk meningkatkan pemahaman peserta didik pada materi Personal Pronouns dan Reported Speech.

\section{Observasi}

Observasi dilakukan secara bersamaan dengan pelaksanaan tindakan yang dilakukan oleh kolaborator, dalam hal ini guru sesama Sejarah (Peminatan). Fokus pemantauan adalah proses penerapan tindakan, aktivitas peserta didik selama pembelajaran yang didasarkan keaktifan serta antusias peserta didik dalam mengerjakan setiap tugas. Pada prestasi belajar sesuai dengan lembar pemantauan dan perangkat evaluasi yang telah disiapkan.

\section{Refleksi}

Hasil pemantauan dan evaluasi dianalisis untuk diperoleh gambaran bagaimana dampak pembelajaran yang telah direncanakan yaitu dengan menerapkan pembelajaran dengan Problem Based Learning (PBL) dengan Role Play. Hasil analisis yang diperoleh merupakan refleksi dari apa yang telah terjadi selama penerapan tindakan pada siklus 1 . Permasalahan pada siklus 1 digunakan sebagai pertimbangan untuk merumuskan perencanaan tindakan pada Siklus 2. Hasil analisis yang diperoleh merupakan refleksi dari apa yang telah terjadi selama penerapan tindakan pada siklus 2. Permasalahan pada siklus 2 digunakan sebagai akhir penelitian tindakan kelas.

\section{HASIL TINDAKAN DAN PEMBAHASAN}

\section{Deskripsi Hasil Siklus 1}

Hasil analisis data menunjukkan bahwa tindakan yang dilakukan pada siklus I cukup berhasil dari beberapa indikator yang sudah terpenuhi bahkan terjadi peningkatan dari kondisi awal antara lain aspek interaksi peserta didik dengan guru yang mencapai $46.87 \%$ lebih tinggi dibandingkan kondisi awal 15.63\%, rasa tanggung jawab peserta didik terhadap proses belajar dan tugas-tugas mereka mencapai $46.87 \%$ dan tingkat kehadiran peserta didik juga tinggi $100 \%$.

Berdasarkan lembar observasi motivasi belajar peserta didik masih banyak peserta didik yang masih kurang kerjasama antara anggota satu dengan yang lain karena masih belum terbiasa dengan metode ini. Walaupun sebenarnya mereka sudah cukup 
Model Pembelajaran Problem Based Learning (PBL)

Sebagai Upaya Meningkatkan Motivasi Dan Prestasi Belajar Sejarah (Peminatan)

(Rus Hartata)

akrab satu dengan yang lain, dalam kegiatan sehari-hari jam sekolah. Berdasarkan hasil observasi, kegiatan peserta didik dalam berinteraksi dengan guru dalam kegiatan kelompok maupun kegiatan lainnya sangat baik, di mana banyaknya peserta didik yang langsung bertanya jika tidak jelas serta antusias peserta didik dalam mengikuti pelajaran terespon dengan baik.

Dari hasil analisa data perkembangan prestasi belajar peserta didik dapat disimpulkan bahwa hasil tes peserta didik yang tuntas mengalami kenaikan dengan nilai batas tuntas 70 keatas, peserta didik yang tuntas belajar di siklus I sebesar $68,75 \%$, yang semula pada tes awal hanya terdapat $31,25 \%$ peserta didik mencapai batas tuntas. Besarnya nilai terendah yang diperoleh peserta didik pada tes awal sebesar 45 pada siklus I naik menjadi 60. Untuk nilai tertinggi terdapat kenaikan dari 75 naik menjadi 90 dan nilai rata-rata kelas yang pada tes awal sebesar 58,91 naik pada tes siklus I menjadi 73,75 .

Dari hasil nilai prestasi belajar diatas ternyata belum mencapai tolak ukur $85 \%$ peserta didik mencapai ketuntasan sehingga diperlukan siklus 2 yang diharapkan sebagai akhir dari tindakan penelitian dengan cara memperbaiki kekurangankekurangan pada siklus 1, sehingga diharapkan pada siklus 2 menjadi bermakna bagi peserta didik dan guru sebagai peneliti. Adanya kekurangan-kekurangan ini dan belum tercapainya $80 \%$ peserta didik tuntas maka perlu adanya siklus 2 sebagai penyempurnaan dari siklus 1 .

\section{Deskripsi Hasil Siklus 2}

Penerapan model pembelajaran Problem Based Learning (PBL) pada siklus 2 terjadi peningkatan dari siklus 1 . Hasil analisis data menunjukkan bahwa tindakan yang dilakukan pada siklus 2 cukup berhasil dari beberapa indikator yang sudah terpenuhi bahkan terjadi peningkatan dari kondisi awal antara lain aspek interaksi peserta didik dengan guru yang mencapai 90\% lebih tinggi dibandingkan dengan Siklus 1 60\%, rasa tanggung jawab peserta didik terhadap proses belajar dan tugas-tugas mereka mencapai $90 \%$ dan tingkat kehadiran peserta didik juga tinggi $100 \%$.

Berdasarkan lembar observasi motivasi belajar peserta didik didapatkan hasil bahwa aspek kerja kelompok, dimana kelompok yang berjumlah 8 kelompok dengan anggota satu kelompok berjumlah 4 peserta didik, hanya ada satu kelompok yang kerja kelompoknya tidak bagus sehingga pada siklus 2 ada 7 kelompok yang bekerjasama 
dengan bagus atau mencapai $87.5 \%$. Pada aspek interaksi peserta didik dengan guru di kelas, peserta didik sudah mulai berinteraksi dengan baik. Guru sudah mulai membimbing dalam mengerjakan tugas-tugas yang telah diberikan oleh guru sehingga peserta didik sudah terbiasa dengan pembelajaran ini.

Dari hasil analisa data perkembangan prestasi belajar peserta didik pada tes dapat disimpulkan bahwa persentase hasil tes peserta didik yang tuntas naik $21,87 \%$ dengan nilai batas tuntas 70 keatas, peserta didik yang tuntas belajar di siklus 2 sebesar 90,63\%, yang semula pada Siklus 1 hanya terdapat $68,75 \%$ peserta didik mencapai batas tuntas. Besarnya nilai terendah yang diperoleh peserta didik pada siklus 1 sebesar 60 pada siklus 2 naik menjadi 65. Untuk nilai tertinggi terdapat kenaikan dari 90 naik menjadi 95 dan nilai rata-rata kelas yang pada Siklus 1 sebesar 73,75 naik pada tes siklus 2 menjadi 80,16 .

Dari hasil nilai prestasi belajar di atas ternyata ketuntasan belajar peserta didik sudah mencapai tolok ukur $80 \%$ yaitu 90,63\%. Dari hasil penelitian pada siklus 2, maka penelitian tidak perlu dilanjutkan pada siklus berikutnya. Namun guru harus terus melaksanakan bimbingan belajar untuk mempertahankan pada hasil belajar dan partisipasi serta suasana dalam kelas sebagai tindak lanjut.

\section{Hasil Tindakan}

Pada pembelajaran dengan metode pembelajaran Problem Based Learning (PBL) yang merupakan metode pembelajaran yang berbasis masalah dan sekaligus sebagai penilaian dalam satu kelompok ternyata dapat membuat peserta didik dalam anggota kelompok sangat tertarik dalam pembelajaran, mereka mulai paham akan materi yang disampaikan pada guru. Pada pembelajaran dengan metode Problem Based Learning $(P B L)$ ternyata membuat peserta didik senang dalam pembelajaran, mereka bisa memahami teori tentang masuknya agama Hindu dan Buddha ke Indonesia serta berdirinya kerajaan Kutai, Tarumanegara, Singosari dan Majapahit.

Pada pembelajaran dengan menggunakan metode pembelajaran Problem Based Learning $(P B L)$ ternyata berdasarkan lembar observasi motivasi belajar peserta didik dapat meningkatkan keempat aspek penilaian motivasi belajar yang dinilai oleh kolaborator dalam pembelajaran, pada pembelajaran di siklus 1 ternyata banyak dari peserta didik yang merasa masih asing dengan pembelajaran Problem Based Learning $(P B L)$, sehingga banyak dari peserta didik yang masih bercakap-cakap dalam 
Model Pembelajaran Problem Based Learning (PBL)

Sebagai Upaya Meningkatkan Motivasi Dan Prestasi Belajar Sejarah (Peminatan)

(Rus Hartata)

pembelajaran, tetapi dalam pembelajaran siklus 2 peserta didik sudah terbiasa dengan pembelajaran Problem Based Learning (PBL), sehingga pembelajaran siklus mempunyai dampak yang baik dalam pembelajaran. Pada nilai prestasi juga terjadi peningkatan nilai rerata dari kondisi awal 58,91 menjadi 80,16 pada kondisi akhir sehingga secara teoritik pembelajaran dengan menggunakan metode pembelajaran Problem Based Learning $(P B L)$ terjadi peningkatan motivasi belajar dan prestasi belajar.

Pada pembelajaran dengan menggunakan metode pembelajaran Problem Based Learning $(P B L)$ ternyata secara empirik didapat hasil sebagai berikut:

1) Motivasi belajar peserta didik dari kondisi awal ke siklus 2 terjadi peningkatan semangat belajar peserta didik terbukti pada lembar obesrvasi motivasi belajar yang dilakukan oleh kolaborator terjadi peningkatan aspek yang diteliti yaitu: pada aspek kerja sama dalam kelompok dari tidak ada kerjasama dalam kelompok menjadi ada kerjasama dalam kelompok, pada aspek interaksi guru dari 15,63\% pada kondisi awal terjadi peningkatan menjadi $93,75 \%$, pada aspek tanggung jawab terjadi peningkatan dari $15,63 \%$ menjadi $93,75 \%$, pada aspek kehadiran peserta didik hadir semua dalam pembelajaran.

2) Prestasi belajar peserta didik terjadi peningkatan dari kondisi awal ke kondisi akhir yaitu pada nilai terendah dari nilai 45 menjadi nilai 65 . Pada nilai tertinggi pada kondisi awal dengan nilai 75 menjadi 95. Pada nilai rerata pada kondisi awal 58,91\% dengan ketuntasan belajar 31,25\% menjadi 80,16 dengan ketuntasan belajar $90,63 \%$.

\section{PENUTUP}

\section{Simpulan}

Berdasarkan kajian teori dan didukung adanya hasil analisis serta mengacu pada perumusan masalah maka dapat disimpulkan sebagai berikut:

1) Pembelajaran dengan mengunakan model Pembelajaran Problem Based Learning $(P B L)$ untuk mata pelajaran Sejarah (Peminatan) bagi peserta didik kelas XI IPS1 SMA Negeri 1 Polokarto pada semester gasal tahun pelajaran 2019/2020 dapat meningkatkan motivasi belajar. Dari kondisi awal ke siklus 2 terjadi peningkatan motivasi belajar bagi peserta didik, terbukti pada lembar observasi motivasi belajar 
yang dilakukan oleh kolaborator terjadi peningkatan aspek yang diteliti yaitu : pada aspek kerja sama dalam kelompok dari tidak ada kerjasama dalam kelompok menjadi ada kerjasama dalam kelompok, pada aspek interaksi guru dari 15,63\% pada kondisi awal terjadi peningkatan menjadi 93,75\% , pada aspek tanggung jawab terjadi peningkatan dari $15,63 \%$ menjadi $93,75 \%$, pada aspek kehadiran peserta didik hadir semua dalam pembelajaran.

2) Pembelajaran dengan mengunakan model Pembelajaran Problem Based Learning $(P B L)$ pada mata pelajaran Sejarah (Peminatan) bagi peserta didik kelas XI IPS1 pada semester gasal SMA Negeri 1 Polokarto tahun pelajaran 2019/2020 dapat meningkatkan prestasi belajar dari kondisi awal ke siklus 2. Dengan terbukti Prestasi belajar peserta didik terjadi peningkatan dari kondisi awal ke kondisi akhir yaitu pada nilai terendah dari nilai 45 menjadi nilai 65 . Pada nilai tertinggi pada kondisi awal dengan nilai 75 menjadi 95. Pada nilai rerata pada kondisi awal 58,91 dengan ketuntasan belajar 31,25\% menjadi 80,16 dengan ketuntasan belajar 90,63\%.

\section{Saran}

Saran yang dapat diberikan peneliti berdasarkan simpulan dan implikasi dalam penelitian ini adalah sebagai berikut:

1) Para guru Sejarah (Peminatan) seyogyanya untuk meningkatkan Prestasi belajar, keaktipan, kreativitas dan keefektipan dalam pembelajaran diharapkan menggunakan Model Pembelaran Problem Based Learning (PBL).

2) Para peserta didik hendaknya dapat berperan aktif dengan menyampaikan ide atau pemikiran, sehingga proses pembelajaran dapat berjalan dengan lancar dan memperoleh hasil belajar yang optimal serta dapat mengaplikasikan hasil belajarnya kedalam kehidupan sehari-hari.

\section{DAFTAR PUSTAKA}

Arends, R. I. 1997. Classroom Instruction and Management. New York: Mc Graw Hill. Azwar, Saifuddin. 2001. Metode Penelitian. Yogyakarta: Pustaka Pelajar.

Budiningsih, Asri. 2005. Belajar dan Pembelajaran. Jakarta: Asdi Mahasatya. 
Model Pembelajaran Problem Based Learning (PBL)

Sebagai Upaya Meningkatkan Motivasi Dan Prestasi Belajar Sejarah (Peminatan)

(Rus Hartata)

Budiyono, 2003. Metodologi Penelitian Pendidikan. Surakarta: UNS Press.

Hamalik, Oemar. 2002. Perencanaan Pengajaran Berdasarkan Pendekatan Sistem. Jakarta: Bumi Aksara.

Kasbolah, Kasihani. 2001. Penelitian Tindakan Kelas. Malang: Universitas Negeri Malang Press.

Kosasih, A dan R. Angkowo. 2007. Optimalisasi Media Pembelajaran. Jakarta: Grasindo.

Peter Salim dan Yenny Salim, 1991. Kamus Bahasa Indonesia Kontemporer. Jakarta: Modern English Press.

Purwanto, M. Ngalim. 1997. Psikologi Pendidikan. Bandung: Remaja Rosdakarya.

Roestiyah, 1989. Strategi Belajar Mengajar. Jakarta: Rineka Cipta.

Sardiman, A.M. 2005. Interaksi dan Motivasi Belajar Mengajar. Jakarta: PT. Raja Grafindo Persada.

Slameto, 2003. Belajar dan Faktor-faktor Yang Mempengaruhinya. Jakarta: Rineka Cipta.

Slavin, Robert E.. 2008. Cooperative Learning (Teori, Riset dan Praktik). Bandung: Nusa Media

Sudjana, Nana. 1989. Cara Belajar Peserta Didik Aktif Dalam Proses Belajar Mengajar. Bandung: Sinar Baru.

1996. Teori-teori Belajar Untuk Pengajaran. Jakarta: UI Press.

Wahyuni, Baharudin Esa Nur. 2007. Teori Belajar dan Pembelajaran. Yogyakarta: ARR422 Media. 